\title{
PELATIHAN PENYUSUNAN PERANGKAT PEMBELAJARAN MILENIAL BAGI GURU SMP-SMA DI KECAMATAN WADENG, KABUPATEN GRESIK
}

\author{
Eko Cahyo Prawoto'), Rahayu Pujiastuti²), Taufik Nurhadi' ${ }^{3)}$ \\ Ira Eko Retnosari ${ }^{4)}$, Indayani ${ }^{5}$ ) \\ 1,2,3,4,5 Program Studi Pendidikan Bahasa Indonesia, Fakultas Keguruan dan Ilmu Pendidikan, \\ Universitas PGRI Adi Buana Surabaya \\ Email:ecahyop@gmail.com,rahayu_pujiastuti30@yahoo.co.id,taufiknurhadi70@gmail.com, \\ ira_eko_80@yahoo.com, indayani16a@gmail.com
}

\begin{abstract}
Abstrak
Setiap pendidik diwajibkan untuk menyusun RPP secara lengkap dan sistematis, untuk menciptakan pembelajaran yang interaktif, efektif, dan menyenangkan sehingga dapat memotivasi peserta didik untuk berpatisipasi secara aktif dalam pembelajaran. Namun demikian, dalam realitasnya masih terdapat banyak kesulitan yang dihadapi oleh pendidik, utamnya dalam menyusun perangkat pembelajaran yang efektif dan efisien. Oleh sebab itu diperlukan pelatihan bagi pendidik dalam menyusun pengakat pembelajaran dalam bentuk Program Pengabdian Kepada Masyarakat. Program Pengabdian Kepada Masyarakat tersebut dilaksanakan oleh Tim Program Studi Pendidikan Bahasa Indonesia pada 3 Februari s.d. 29 Februari 2020. Dengan tema "Peningkatan Kualitas Pembelajaran Menuju Merdeka Belajar" Subtema "Penyusunan Perangkat Pembelajaran Milenial", direncanakan selama 1 bulan sesuai dengan program Prodi Pendidikan Bahasa Indonesia semester Genap 2020 UNIPA Surabaya. Kegiatan PPM yang diselenggarakan oleh Tim Prodi PBI UNIPA Surabaya berjalan dengan baik. Hal tersebut dapat dilihat dari hasil pelatihan yang telah dilaksanakan, bahwa semua peserta dapat menyusun perangkat pembelajaran milenial, serta hampir semua peserta (30 orang) memberikan respon positif terkait dengan pelatihan yang dilaksanakan. Sebab peserta mendapat banyak wawasan baru utamanya berkaitan dengan penyusunan perangkat pembelajaran milenial, melalui pelatihan perangkat pembelajaran milenial diharapakan dapat digunakan sebagai formula baru untuk merancang pembelajaran yang lebih efektif serta efisien.
\end{abstract}

Kata kunci: merdeka belajar, perangkat pembelajaran milenial

\begin{abstract}
Every educator is required to compile lesson plans in a complete and systematic manner, to create interactive, effective and enjoyable learning so that they can motivate students to actively participate in learning. However, in reality there are still many difficulties faced by educators, especially in developing effective and efficient learning tools. Therefore training is needed for educators in preparing teaching learning in the form of Community Service Programs. The Community Service Program was implemented by the Indonesian Language Study Program Team on 3 February s.d. 29 February 2020. With the theme "Improving the Quality of Learning Towards Freedom of Learning" Sub-theme "Arrangement of Millennial Learning Tools", planned for 1 month in accordance with the Indonesian Language Education Study Program program in the even semester of 2020 UNIPA Surabaya. PPM activities organized by PBI UNIPA Surabaya Study Program Team went well. This can be seen from the results of the training that has been carried out, that all participants can arrange millennial learning tools, and almost all participants (30 people) give positive responses related to the training conducted. Because participants get a lot of new insights, especially related to the preparation of millennial learning tools, through training on
\end{abstract}


millennial learning tools, it is hoped that they can be used as a new formula for designing more effective and efficient learning.

Keyword: free learning, millenial learning tools.

\section{PENDAHULUAN}

Pendidikan adalah salah satu upaya untuk menjadikan manusia menjadi lebih baik, melalui jenjang pendidikan pada sekolah formal maupun non formal. Uno (2008:11) menyatakan, pendidikan merupakan aktivitas pemberdayaan yang bertujuan untuk menjadikan manusia lebih terdidik, cerdas, berpengetahuan, serta berilmu. Oleh sebab itu, melalui proses pembelajaran diharapkan peserta didik dapat mengembangkan potensinya, sehingga dapat memberi manfaat bagi kehidupan masyarakat.

Pada pendidikan formal terdapat beberapa komponen penting di dalamnya, salah satu komponen terpenting ialah guru. Sebab guru adalah aktor utama dalam merancang, mengembangkan, melaksanakan, serta mengevaluasi pembelajaran. Alton dalam Gurney (2007: 90), guru memiliki pengaruh yang sangat besar terhadap kualitas pembelajaran yang dilakukan. Sebab guru memiliki pengetahuan akan karakter masing-masing peserta didik, sehingga dapat merancang pembelajaran sesuai dengan kebutuhan perserta didik.

Guru yang berkualitas, selalu memiliki perencanaan yang matang dalam mempersiapkan pembelajaran, melalui penyusunan perangkat pembelajaran. Karena perangkat pembelajaran adalah salah satu komponen penting dalam mencapai tujuan pembelajaran. Menurut Nazarudin (2007 : 111) perangkat pembelajaran adalah upaya yang dilakukan oleh guru dalam persiapan pembelajaran, baik disusun secara individu maupun kelompok (KKG maupun MGMP) untuk memudahkan pelakasanaan dan evaluasi pembelajaran secara sistematis untuk mencapai tujuan pembelajaran yang diinginkan.

$$
\text { Suparno (2002) menyatakan }
$$$$
\text { bahwa sebelum melaksanakan proses }
$$

pembelajaran seorang pendidik diharapkan mempersiapkan bahan, mempersiapkan alat peraga/alat praktikum, mempersiapkan pertanyaan dan arahan untuk merangsang siswa agar lebih aktif dalam pembelajaran, mempelajari keadaan peserta didik.

Selain itu, Suhadi (2007) menyatakan, perangkat pembelajaran terdiri atas beberapa komponen, diantaranya ialah; Prota, Promes, RPP, buku ajar, lembar kerja peserta didik, dan perangkat evaluasi pembelajaran (soalsoal ulangan harian/tengah semester/akhir semester, dsb).

Pendapat tersebut diperkuat dengan terbitnya PP Nomor 19 Tahun 2005 Pasal 20 yang menyatakan bahwa "Perencanaan proses pembelajaran meliputi silabus dan rencana pelaksanaan pembelajaran yang memuat sekurang-kurangnya tujuan pembelajaran, materi ajar, metode pengajaran, sumber belajar, dan penilaian hasil belajar".

Berdasarkan beberapa paparan tersebut, setiap pendidik diwajibkan untuk menyusun RPP sesuai dengan ketentuan format dan disusun secara sistematis, untuk menciptakan pembelajaran yang interaktif, efektif, dan menyenangkan sehingga dapat merangsang peserta didik untuk berpatisipasi secara aktif dalam pembelajaran. Namun demikian, dalam realitasnya masih terdapat banyak kesulitan yang dihadapi oleh para pendidik, utamnya dalam menyusun perangkat pembelajaran yang efektif dan efisien.

dapun kesulitan yang dihadapi oleh pendidik dalam menyusun RPP di antaranya; 1) pada umumnya pendidik belum memiliki pemahaman secara utuh pada tiap-tiap komponen yang terdapat dalam RPP serta bahan ajar yang lain; 2) kurangya motivasi pendidik untuk membaca serta memahami peraturan-peraturan tentang pembelajaran; 3) kemudahan mendapatakan RPP menyebabkan guru tidak memiliki motivasi dalam merancang RPP secara mandiri dengan menyesuaikan kebutuhan, serta 
PENAMAS ADI BUANA

Volume 04, Nomor 1, 01 Juli 2020
P ISSN 2622-5727

E ISSN 2622-5395 karakter peserta didik; 4) sebagian besar pendidik masih berpikir jika penyusunan RPP hanya pemenuhan administrasi; 5) perubahan kurikulum sedikit banyak berdampak dalam perubahan komponen dalam RPP, yang dapat menyulitkan pendidikan dalam menyusun perangkat pembelajaran; (6) minimnya penguasaan teknologi komputerisasi para pendidik, terutama para pendidika yang sudah memiliki usia lanjut.

Menyikapi

permasalahanpermasalahan yang terkait dengan perencanaan pembelajaran, Pemerintah melalui Kementerian Pendidikan dan Kebudayaan menerbitkan edaran No. 14 Tahun 2019 Tentang penyederhanaan RPP menerbitkan format baru RPP. Surat tersebut ditujukan kepada Kepala Dinas Pendidikan Provinsi dan Kabupaten/Kota di seluruh Indonesia ini, sesuai namanya, dimaksudkan untuk menyederhanakan format penyusunan RPP, sehingga lebih efisien, efektif dan berorientasi pada peserta didik. Adapun penyederhanaan dalam RPP sesuai edaran tersebut ialah; 1) tujuan pembelajaran, 2) langkah-langkah pembelajaran, 3) penilaian pembelajaran atau (asesment).

Berdasarkan fakta tersebut, diperlukan sosialisasi dan pelatihan dalam bentuk Pengabdian Kepada Masyarakat (PPM) kepada para pendidik dalam yang dilakukan oleh Program Studi Pendidikan Bahasa Indonesia, Universitas PGRI Adi Buana Surabaya (UNIPA Surabaya), guna memberi solusi terkait dengan permasalahanpermasalahan yang mucul dalam penyusunan perangkat pembelajaran milenial. Adapun kegiatan pengabdian pada masyarakat ini memiliki tujuan untuk:

1. memberikan wawasan mengenai pembelajaran menuju merdeka belajar;

2. memberikan wawasan dan keterampilan dalam menerapkan critical thingking dalam pembelajaran;

3. memberikan wawasan dan keterampilan dalam menyusun model pembelajaran;
4. memberikan wawasan dan keterampilan dalam menyusun perangkat pembalajaran milenial.

Selanjutnya, Program Studi Pendidikan Bahasa Indonesia menentukan kelompok sasaran dalam kegiatan itu, yakni para pendidik SMP dan SMA di desa Wadeng, Kecamatan Sidayu, Kabupaten Gresik. Hal tersebut dilakukan sebab melihat beberapa permasalahan di atas, terkait dengan kesulitan-kesulitan pendidik dalam menyusun perangkat pembelajaran yang sesuai dengan kebutuhan generasi milenial. Jenjang SMP dan SMA

Berdasarkan hasil observasi di lapangan yang telah dilakukan pada 15 Januari 2020 di beberapa sekolah baik di Jenjang SMP dan SMA di Desa Wadeng, Kecamatan Sidayu, Kabupaten Gresik, diperoleh informasi mengenai kondisi tenaga pendidik sebagai berikut.

1. Pengetahuan tentang perangkat pembelajaran milenial: Secara mayoritas pendidik di baik SMP maupun SMA di Desa Wadeng, Kecamatan Sidayu, Kabupaten Gresik, belum mampu menyusun perangkat pembelajaran yang sesuai dengan karakter milenial

2. Jumlah Pendidik: 30 orang

3. Model perangkat pembelajaran yang disusun dan digunakan masih belum mengacu pada edaran menteri nomor 14 Tahun 2019.

4. Pengetahuan tentang perangkat pembelajaran milenial: Masih perlu ditingkatkan. Oleh sebab itu, diperlukan pelatihan untuk memberikan wawasan tentang pentingnya penyusunan perangkat pembelajaran milenial

5. Pemahaman akan peserta didik generasi milenial: Perlu pelatihan untuk memberikan wawasan secara garis besar mengenai karakteristik generasi milenial. 
PENAMAS ADI BUANA

Volume 04, Nomor 1, 01 Juli 2020
Pada artikel ini, kegiatan hanya difokuskan pada poin (a) dan (d), yaitu memberi wawasan mengenai pembelajaran menuju merdeka belajar, khususnya penyusunan perangkat pembelajaran milenial utamanya ialah RPP.

\section{METODE PELAKSANAAN}

Pelaksanaan program dilakukan dengan menjalin kemitraan dengan para pendidik tingkat SMP-SMA di Kecamatan Sidayu Kabupaten Gresik. Dalam melaksanakan kegiatan Peningkatan Kualitas Pembelajaran Menuju Merdeka Belajar Subtema Penyusunan Perangkat Pembelajaran Milenial dilakukan dengan metode direct instruction adapun tahapan pelaksanaan ialah sebagai berikut: 1) penyajian materi wawasan generasi meilenial, secara interaktif, 2) penyajian materi perangkat pembelajaran milenial, 3) diskusi mengenai model perangkat pembelajaran milenial, 4)praktik penyusunan perangkat pembelejaran milenial, 4) evaluasi dan refleksi.

Program Pengabdian Kepada Masyarakat tersebut dilaksanakan oleh Tim Program Studi Pendidikan Bahasa Indonesia pada 3 Februari s.d. 29 Februari 2020. Waktu pelaksanaan kegiatan tersebut disesuaikan dengan situasi dan kondisi di lapangan. Peningkatan Kualitas Pembelajaran Menuju Merdeka Belajar Subtema Penyusunan Perangkat Pembelajaran Milenial, direncanakan selama 1 bulan sesuai dengan program Prodi Pendidikan Bahasa Indonesia semester Genap 2020 UNIPA Surabaya.

\section{HASIL DAN PEMBAHASAN}

Dalam pelaksanaan kegiatan PPM oleh Program Studi Pendidikan Bahasa Indonesia (PBI) yang diikuti oleh 30 guru SMP-SMA se-Kecamatan Sidayu, Gresik terbagi menjadi beberapa kegiatan berikut;

1. TIM menjelaskan tentang wawasan merdeka belajar dari segi peraturan maupun proses-proses kegiatan merdeka belajar yang dapat dilaksanakan di sekolah.
2. Selanjutnya, paparan tentang critical thingking yang perlu ditanamkan pada siswa dalam proses pembelajaran, serta penjelasan tentang keterampilan dalam menerapkan critical thingking dalam pembelajaran.

3. Menjelaskan wawasan dan keterampilan dalam menyusun model pembelajaran yang dapat diterapkan proses pembelajaran dalam meningkatkan critical thingking pada siswa.

4. Kemudian dilanjutkan dengan penjelasan tentang wawasan dan keterampilan dalam menyusun perangkat pembelajaran milenial.

\subsection{Penyusunan RPP}

Guna melengkapi wawasan yang diperoleh peserta, selanjutnya adalah kegiatan praktikum penyusunan perangkat pembelajaran milenial khususnya RPP. Pada kegiatan ini peserta pelatihan diminta untuk menyusun perangkat pembelajaran. Adapun tahapan pelatihan dalam penyusunan perangkat pembelajaran milenial ialah sebagai berikut.

1. Peserta menuliskan identitas pada RPP sesuai dengan sekolah masingmasing.

2. Peserta menyusun tujuan pembelajaran yang merujuk pada kurikulum 2013 serta kebutuhan belajar peserta didik. Pada tahap ini peserta diminta untuk dapat mendeskripsikan proses pembelajaran serta hasil pembelajaran dengan menggunakan pilihan kata yang operasional yang terukur.

3. Selanjutnya peserta menguraikan langkah-langkah pada setiap proses pembelajaran, yang ditulis secara efektif berupa aktifitas pembelajaran yang secara langsung mencapai kompetensi dasar. Penulisan langkah-langkah pembelajaran mengedepankan aktifitas yang inspiratif dan menyenangkan. Hal tersebut, 
PENAMAS ADI BUANA

Volume 04, Nomor 1, 01 Juli 2020
P ISSN 2622-5727

E ISSN 2622-5395 bertujuan untuk mengajak peserta didik menjadi lebih aktif, memberikan ruang untuk berkreatifitas dan kemandirian belajar, menyalurkan minat dan bakat, dan perkembangan fisik serta psikologisnya. Penyusunan langkah-langkah pembelajaran tetap memperhatikan komponen keterampilan abad 21, meliputi; Penguatan Pendidikan Karakter (PPK), 4C (literasi, critical thingking, creatif thingking, collaboration, dan communication) serta keterampailan tingkat tinggi (berbasis HOTS).

4. Selanjuutnya peserta menyusun penilian pembelajaran, penilaian pembelajaran ditulis secara sederhana namun tetap mengacu pada indikator pencapaian kompetensi dan standar penilaian. Terdapat tiga bentuk penilaian dalam pembelajaran abad 21, yanki; assessment for learning, assessment asa learning, dan assessment of learning.

Pada parktik penyusunan RPP yang mengacu pada edaran Edaran Nomor 14 Tahun 2019 tentang Penyederhanaan RPP. Melalui peraturan tersebut pendidik lebih memiliki ruang untuk memodifikasi RPP sesuai dengan capaian pembelajaran, sebab tiap RPP yang disusun lebih kurang 1 sampai 2 halaman. Dengan demikian diharapkan pendidik tidak terlalu terbebani dengan kegiatan administrasi perencanaan pembelajaran

\subsection{Hasil Pelatihan}

Pada bagian ini akan dijelaskan hasil pelatihan serta refleksi yang dilakukan oleh TIM Prodi PBI; 1) hasil pelatihan yang diperoleh ialah peserta dapat menyusun perangkat pembelajaran milenial yang sederhana, serta dapat dikembangkan secara individu dengan tetap memperhatikan esensiesensi pokok perangkat pembelajaran. 2) refleksi pelatihan dilakukan untuk memperoleh argumentasi, pesan, serta kesan dari peserta selama mngikuti pelatihan, hasil refleksi nantinya digunakan sebagai salah satu umpan balik untuk perbaikan PPM yang diselenggarakan pada periode selanjutnya. Dalam kegiatan refleksi tersebut setiap peserta diberi kesempatan untuk menyampaikan beberapa hal tersebut. Selain itu, peserta juga diminta untuk mengisi kuisioner tentang, materi pelatihan, pemateri, fasilitas yang disediakan. Berdasarkan pendapat serta kuisioner mengenai beberapa aspek tersebut bahwa hampir semua peserta (30 orang) dapat menyerap materi pelatihan dengan baik. Hal tersebut terlihat pada RPP yang dihasilkan oleh masing-masing peserta.

\section{KESIMPULAN}

Berdasarkan pembahasan di depan dapat diperoleh simpulan bahwa RPP adalah perangkat penting bagi seorang pendidik. Sebab RPP merupakan pedoman dalam pelaksanaan pembelajaran, sehingga proses pembelajaran menjadi lebih terarah serta dapat tercapainya tujuan pembelajaran. Namun demikian komponen RPP yang begitu banyak dapat menyebabkan guru menjadi malas untuk merencanakan pembelajaran, melalui pelatihan perangkat pembelajaran milenial yang cenderung sederhana diharapakan dapat digunakan sebagai formula baru untuk merancang pembelajaran yang lebih efektif serta efisien.

Kegiatan PPM yang diselenggarakan oleh Tim Prodi PBI UNIPA Surabaya berjalan sesuai dengan capaian yang telah ditetapkan. Hal tersebut dapat dilihat dari hasil pelatihan yang telah dilaksanakan, bahwa semua peserta dapat menyusun perangkat pembelajaran milenial, serta hampir semua peserta (30 orang) memberikan respon positif terkait dengan pelatihan yang dilaksanakan. Sebab peserta mendapat banyak wawasan baru utamanya berkaitan dengan penyusunan perangkat pembelajaran milenial.

\section{REFERENSI}

Gurney, Philip. 2007. "Five Factors for Effective Teaching". New Zealand Journal of Teacher's Work Vol. 4: 8998. Diakses pada 14 Maret 2017 
PENAMAS ADI BUANA

Volume 04, Nomor 1, 01 Juli 2020

(www.teacherswork.ac.nz/journal/vol ume4 issue2/gurney.pdf)

Nazarudin. 2007. Manajemen Pembelajaran : Implementasi,

Konsep, Karakteristik, Metodologi Pendidikan Agama Islam di Sekolah Umum. Yogyakarta : Teras.

Suparno. 2001. Teori Perkembangan Kognitif Jean Piaget. Yogyakarta: Kanisius.

Suhadi. 2007. Petunjuk Perangkat Pembelajaran. Surakarta: Universitas Muhamadiah.
P ISSN 2622-5727

E ISSN 2622-5395

Pemerintah Indonesia. 2005. Peraturan Pemerintah Nomor 19 Tahun 2005 tentang Standar Pendidikan Nasional. Jakarta: Sekretariat Negara.

Pemerintah Indonesia. 2019. Edaran Nomor 14 Tahun 2019 tentang Penyederhanaan RPP. Nasional. Jakarta: Sekretariat Negara.

Uno, Hamzah .B 2008. Profesi Kependidikan : Problema, Solusi, dan Reformasi Pendidikan di Indonesia. Jakarta : PT Bumi Aksara 